\title{
Filosofía Clínica y Filosofía ApliCAda: UN DIÁLOGO POTENCIAL Y ACTUAL
}

\author{
Clinical Philosophy And Philosophical Practice: A \\ POTENTIAL AND ACTUAL DIALOGUE
}

\author{
LEONARDO RicCo MEDEIROS \\ Universidad de Sao Paulo \\ leoricco@usp.br
}

RECIBIDO: 2 DE ENERO DE 2018

ACEPTADO: 5 DE FEBRERO DE 2018

Resumo: Neste artigo encontramos o texto que serviu de base para fala proferida no II Diálogo Nacional de Filosofia Clínica, no Brasil, em outubro de 2017. Proposta sob o título "Filosofia Aplicada à Pessoa: dialogando com José Barrientos Rastrojo", a comunicação toca em pontos fundamentais para a prática filosófica voltada à complexidade do "ser pessoa", expondo a diferença básica entre Filosofia Aplicada Lógico Argumentativa (FALA) e Filosofia Aplicada Experiencial (FAE). Além de propor um diálogo com a Filosofia Clínica, enxergando possibilidades de aproximação e distinção, em meio à conversa são sugeridas reflexões acerca do diálogo dito democrático, da Cosmocracia (Huberto Rohden) e de um possível deslocamento na atual forma de pensar a política. Para apresentar o texto, o autor propõe a Educação como veiculada à Filosofia Aplicada à Clínica e a necessária conscientização da distinção entre os pensamentos filosófico, científico, artístico e de senso comum opinativo.

Palabras chave: Filosofía Aplicada, Filosofía Clínica, Cosmocracia, Educaçao, Filosofía-ciência-arte.

\begin{abstract}
In this article, we present the text that served as the basis for the speech given at the 2nd National Dialogue of Clinical Philosophy, which took place in Brazil, in October 2017. Under the title "Philosophy Applied to the Person: dialoguing with José Barrientos Rastrojo", the communication covers key points of the philosophical practice focused on the complexity of the human being, exposing the basic difference between Logical Argumentative Applied Philosophy (LAPA) and Experiential Applied Philosophy (EAP). In addition to proposing a dialogue with Clinical Philosophy, seeing possibilities of approaching and detecting differences, some reflections are suggested during the
\end{abstract}


talk relating to the so-called democratic dialogue, Cosmocracy (Hubert Rohden) and a possible shift in the current way of thinking politics. In order to present the text, the author proposes Education as being linked with Philosophy Applied to Clinical Practice and the necessity of raising awareness of the distinction between philosophical, scientific, artistic and opinionated common-sense thoughts.

Keywords: Philosophical practices, Clinical Philosophy, Cosmocracy, Education, Philosophy-science-art

No Brasil, de doze a catorze de outubro de 2017, na cidade de Belo Horizonte, estado de Minas Gerais, acontecia-nos ${ }^{1}$ o II Diálogo Nacional em Filosofia Clínica. A proposta de um "Diálogo" com amplitude de nação surgiu como um acréscimo a outros eventos, como os Colóquios e os Encontros Nacionais de Filosofia Clínica estes últimos ocorrendo no país desde a década de mil novecentos e noventa. Os "Diálogos" nacionais (oficialmente quantificados em duas edições) nasceram como um nome alternativo aos regionais Encontros Mineiros que, na ocasião, situavam-se em sua décima quinta (XV) edição. Apresentaremos aqui, com alguns pequenos ajustes e acréscimos, o texto que apoiou a fala ou comunicação que fizemos no evento.

Ao considerar as distinções ocasionadas pelos aprofundamentos etimológicos com os termos, encantou-nos que o título previamente definido para nossa palestra era "Filosofia Aplicada à Pessoa: dialogando com José Barrientos Rastrojo". O estar sendo, com o gerúndio do verbo dialogar, abriu portas para que especialmente considerássemos um devir qualquer com o conceito de diálogo (do

\footnotetext{
1 “A experiência é o que nos passa, o que nos acontece, o que nos toca. Não o que se passa, não o que acontece, ou o que toca. A cada dia se passam muitas coisas, porém, ao mesmo tempo, quase nada nos acontece". En: LARROSA BONDÍA, Jorge: Tremores: escritos sobre experiência, Autêntica, Belo Horizonte, 2015.
} 
diálogo nacional, regional e das pessoas próximas, virtual ou presencialmente).

A Filosofia Aplicada, conforme a desenvolve José Barrientos e colaboradores, aproxima-se da Filosofia Clínica sobremaneira em 2014, quando da sexta Jornada de Estudos ao Exterior organizada pelo Instituto Packter no Brasil e vinculada ao Seminário "A escola de Ortega e a de Lúcio Packter", realizada na Universidade de Sevilla, Espanha.

Particularmente, temos entendido a Filosofia Clínica como uma Escola de Filosofia autêntica ${ }^{2}$. Tal autenticidade - no sentido mesmo orteguiano de responder vitalmente a um íntimo chamado por um singular caminho - faz-se presente ao lado da constatação verídica das relações possíveis de seu instrumental com a tradição fenomenológica ou com um amálgama de elementos envolvendo analítica da linguagem, logicismo formal, epistemologia, empirismo inglês, pragmatismo e historicismo.

Criada em meio à proximidade com rotinas e vivências de uma família de médicos e de aproximações estudantis ${ }^{3}$ com a Psiquiatria, a Filosofia Clínica ${ }^{4}$ poderia ainda, validamente,

2 RICCO MEDEIROS, Leonardo: "Filosofia Clínica, Aconselhamento Filosófico, Saúde e Educação", en Educação - Revista científica do Centro Universitário Claretiano, volumen 7, Batatais, 2017a. Págs. 77-108. "Clinical Philosophy, Esoterism, Method and Methodology - Actions, hypotheses and experimentations at the 1st Luso-Brazilian Course of Clinical Philosophy", traducido al inglés por Marcelo Batistella, en Partilhas: Revista de Filosofia Clínica do IMFIC, volumen 3, Poços de Caldas, 2016. Págs. 105-119. "El filósofo (clínico) y el tartamudo extranjero", traducido al español por Marcelo Batistella, en Partilhas: Revista de Filosofia Clínica do IMFIC, volumen 4, Poços de Caldas, 2017b. Págs. 145-158.

${ }^{3}$ No sentido da música de Milton Nascimento (1969), Coração de Estudante: "Há que se cuidar da vida / Há que se cuidar do mundo / Tomar conta da amizade / Alegria e muito sonho / Espalhados no caminho / Verdes, planta e sentimento / Folhas, coração / Juventude e fé".

${ }^{4}$ Recomendamos a leitura da Conferência de abertura do XVI Encontro Nacional de Filosofia Clínica, em 18 de setembro de 2014, em Forquilhinha-SC, "O que é 
estimular teses que a aproximassem de movimentos vinculados à Anti-Psiquiatria (David Laing, Ronald Cooper, Thomas Szasz), a Rede de alternativas à Psiquiatria e a Psiquiatria Alternativa (Monique Elkaim, Giovanni Jervis, Felix Guattari, Sylvia Marcos, Alfredo Moffatt), a Psiquiatria Comunitária (Gerald Caplan, Wolfgang Huber) e a Psiquiatria Democrática italiana (Agostino Pirella, Vieri Marzi, Giovanni Jervis, Franco Basaglia) ${ }^{5}$. Mesmo no Brasil, seu país natal, não seriam poucas as referências eventualmente eleitas para participar da polifonia envolvida no zeitgeist (espírito do tempo) de sua criação.

A Reforma Psiquiátrica brasileira, "um processo social amplo e complexo", remete-nos a escritos literários de Machado de Assis (O alienista, de 1881) e Lima Barreto (Cemitério dos Vivos, de 1920), aos trabalhos pioneiros de psiquiatria social de Ulisses Pernambucano no Recife (década de 1930), a utilização da expressão artística como instrumento terapêutico por Ozório César (década de 1920) e Nise da Silveira (década de 1940) e às experiências com comunidades terapêuticas na década de 1960, em São Paulo e Rio Grande do $\mathrm{Sul}^{6}$. Não nos parece improvável considerar a Filosofia Clínica de Lúcio Packter e colaboradores como uma participante ativa deste complexo processo que envolve a transformação da práxis da assistência em saúde mental e a compreensão ampliada do processo saúde-doença. Instrumentos ou estratégias, por exemplo, do Sistema Único de Saúde (SUS) brasileiro e a Política Nacional de Humanização (Humaniza SUS) -

Filosofia Clínica”, na qual Lúcio Packter faz um resumo de como foi construída a Filosofia Clínica a partir de meados dos anos 80 .

5 Para uma primeira aproximação acerca da existência destes movimentos, sugerimos SERRANO, Alan Indio: $O$ que é psiquiatria alternativa, Brasiliense, São Paulo, 1986.

6 YASUI, Sílvio: "Rupturas e encontros: desafios da Reforma Psiquiátrica Brasileira", Tese (Doutorado em Ciências na área de Saúde) - Escola Nacional de Saúde Pública da Fundação Oswaldo Cruz, Rio de Janeiro, 2006. p. 208f. 
como a "Clínica Ampliada", as "Equipes de Referência" e os "Projetos Terapêuticos Singulares"7 - encontram semelhanças de sentido com o propósito do filósofo clínico em cuidar, escutar, aproximar-se e acolher o singular filosófico das pessoas que com ele se relacionam partilhando trajetórias existenciais.

Nossa caminhada com a Filosofia Clínica vai sendo tecida em meio a hipóteses, ações e experimentações que colocam a Filosofia como um pensamento em devir existente com a criação de conceitos pessoalmente vivos e singulares; conceitos que fazem surgir acontecimentos pelo encontro e ação de forças-afetos em uma narrativa existencial única. Também nos aparece a Filosofia enquanto atitude de "troca de ideias", conversa ou interlocução envolvendo estilos, tendências, tradições e jogos de linguagem que cabem tanto em uma classificação didático-disciplinar clássica (Ética, Física e Lógica) quanto mais moderna (Ética, Política, Metafísica $^{8}$, Estética, Lógica, Epistemologia). Com o filósofo

${ }^{7}$ BRASIL: Clínica ampliada e compartilhada, Ministério da Saúde, Secretaria de Atenção à Saúde, Política Nacional de Humanização da Atenção e Gestão do SUS, Ministério da Saúde, Brasília, 2010.

${ }^{8}$ Lemos em POLITZER, Georges: Princípios fundamentais de filosofia, tradução de João Cunha Andrade, Fulgor, São Paulo, 1962: “a dialética se opõe radicalmente à metafísica. $\mathrm{O}$ metafísico separa aquilo que, na realidade, não é separável" (p.35). Cai assim em um paradoxo: faz-se metafísico ao separar metafísica de dialética, ao invés de distingui-las e integrá-las. "Quando falamos em método metafísico estamos, com essa expressão, querendo significar um método que ignora e desconhece a realidade do movimento e da transformação. (...) A metafísica ignora o movimento em favor do repouso, a transformação em favor do idêntico. (...) Para o metafísico o homem é eterno, logo, é imutável. Por que? Porque separa o homem do seu meio, a sociedade" (p.26). Estamos atentos ao alerta de Politzer, inspirado no pensamento crítico da dialética marxista e materialista. Porém, entendemos que o estudo do ser (seja ele denominado metafísica ou ontologia) não ignora a existência do movimento e da transformação dos versos, mas procura integrá-la à ideia de uma essência "taoística", unitária. Homem e sociedade estão intrinsicamente unidos, assim como o existente e o essencial, a vida singular e o sentido da vida singular, a vida 
Huberto Rohden, suspeitamos ainda que possam ser nomeados por Filosofia movimentos que, ultrapassando o intelecto e o discurso que analisam causas individuais, avançam rumo ao uso da intuição não-discursiva, saboreando a causa última, universal e integral dos fenômenos e das causas individuais". O sabor do "sentido escondido por trás de cada situação singular" ${ }^{\prime 10}$.

Enquanto vai sendo em uma dimensão existencial própria do ego intelectual, a Filosofia (esteja ela aplicada em clínica ou não) caminha consciente de suas diferenças e parcerias intercomplementares com os funcionamentos de senso comum opinativo e dos pensamentos da Ciência e da Arte ou pensamentos científico e artístico. Ambos participam integralmente, junto à Filosofia, da busca incessante e infinita pelo conhecimento verdadeiro (episteme).

Do pensamento via ciência entendemos uma opção pelo olhar da demonstração e da comprovação; uma escolha de proposições ou funções afirmativas utilizando variáveis quantificadoras ou quantificadas, que abrem mão do infinito para considerar o limite

universal e a vida particular. Consideramos que Filosofia é mais do que 'um acho que baseado em' ou um 'gosto ou não gosto de'; é um 'ser possível pensar em'.

${ }^{9}$ ROHDEN, Huberto: Filosofia contemporânea: o drama milenar do homem em busca da verdade integral, Martin Claret, São Paulo, 2008. O espírito da filosofia oriental: o drama milenar do homem em busca da verdade integral. 3. ed. Martin Claret, São Paulo, 2013.

10 FRANKL, Viktor: A vontade de sentido: fundamentos e aplicações da Logoterapia, tradução de Ivo Studart Pereira, Paulus, São Paulo, 2011. "Na era do vácuo existencial [...] parece que o papel da Educação, mais do que transmitir tradições e conhecimentos, deveria ser o de refinar a capacidade humana de encontrar sentidos únicos. [...] deve, sim, encorajar e desenvolver a capacidade individual da tomada de decisões autênticas e independentes. Numa era em que os Dez Mandamentos parecem ter perdido sua validade incondicional, o ser humano tem de aprender, mais do que nunca, a ouvir os dez mil mandamentos relacionados às dez mil situações singulares nas quais sua vida consiste. Quanto a tais mandamentos, o ser humano deve reportar-se à sua consciência, confiando a ela seu papel de guia" (p. 84). 
dos métodos e o mapeamento claro de coordenadas, definições e referências intersubjetivas, participando da invenção e modificação de critérios para o verdadeiro e o falso estatístico. Do pensamento via arte, de difícil definição por sua natureza ao mesmo tempo equívoca, ambígua, técnica e conceitual (vide a "arte conceitual"), parece-nos que participa do infinito sem necessariamente se pronunciar explicativamente sobre ele; os movimentos do pensar artístico fluem na produção e fruem na contemplação junto a sensações-percepções, emoções e interpretações ligadas a variedades de experiências com cores, sons, cheiros, sabores, formas e sinestesias. Tanto as pronunciadas certezas científicas quanto as variadas expressões artísticas confirmam o infinito filosófico e participam das experiências singulares de criações (criadouros) conceituais.

A Filosofia Aplicada em Clínica ou a Filosofia Clínica Aplicada aparece-nos, ainda, intrinsicamente ligada ao conceito de Educação. A clínica filosófica ${ }^{11}$ é um espaço de exercício existencial e um espaço educativo. Temos investigado possibilidades para pensar o sentido educacional em nossa prática de atendimentos e relacionamentos filosófico-clínicos apoiandonos em trabalhos de Huberto Rohden. Há dois de especial destaque para a questão educativa. O primeiro deles, "Novos rumos para a Educação" $"$, originou-se de uma série de conferências sobre a proposta de uma nova forma de democracia - a cosmocracia realizadas em 1958 e 1959 no auditório do Ministério da Educação

\footnotetext{
11 O nome "clínica" explica-se historicamente pela inicialmente concebida aplicação da filosofia no ambiente médico-clínico. A parte destas possíveis referências, na prática, a Filosofia dita Clínica, conforme desenvolvida por Packter e os variados centros de formação no Brasil, entende a clínica filosófica possível de ser desenvolvida tanto no espaço de "clínica-consultório", como em cafés, encontros, praças, salas de aula, praias, casas, caminhadas, etc..

${ }^{12}$ ROHDEN, Huberto: Novos rumos para a educação, Martin Claret, São Paulo, 2005b.
} 
no Rio de Janeiro. A outra, "Educação do Homem Integral"13, foi escrita sob o motivo da promulgação do Decreto-lei $\mathrm{n}^{\circ} 869$, de 1969, que pretendia estabelecer uma base filosófica para a Educação. Nestas obras está presente (implicitamente na primeira e explicitamente na segunda) a premissa que "ninguém pode educar alguém", visto que a educação propriamente dita compõe-se de movimentos singulares de auto-educação ("alguém só pode educarse a si mesmo" ou a "verdadeira educação é essencialmente intransitiva, ou reflexiva, subjetiva") ${ }^{14}$.

Podemos pensar proximidades com o pensamento cético de Pirro de Ellis conforme a proposição "nada pode ser ensinado, pois ou você ensina o que a pessoa já sabe e, portanto, isto não é ensinar algo; ou você ensina algo obscuro que não será compreendido, não existindo aprendizado e, por isso mesmo, ensino" "15. Também, quem sabe, com o sofista Górgias com seu fragmento "nada existe que possa ser conhecido; se pudesse ser conhecido, não poderia ser comunicado; se pudesse ser comunicado, não poderia ser compreendido"16. Ou, Fernando Pessoa, quando diz que "quem não entende [uma obra, que, por natureza, sempre falará com a voz que lhe é própria] não pode entender, e não há pois que explicar-lhe; é como fazer compreender a alguém um idioma que ele não fala" ${ }^{" 17}$. Algum sentido parecido pode aparecer no que escreveu

${ }^{13}$ ROHDEN, Huberto: Educação do homem integral, Martin Claret, São Paulo, 2005 a.

${ }^{14}$ ROHDEN, Huberto: Educação do homem integral. Martin Claret: São Paulo, 2005a. Págs. 17, 19, 85.

${ }^{15}$ Proposição adaptada de: FATTURI, Arturo: Teoria do conhecimento I: livro didático, UnisulVirtual, Palhoça, 2009. Livro didático da disciplina de Teoria do Conhecimento I do curso EaD de bacharelado em Filosofia da Unisul Universidade do Sul de Santa Catarina. Pág. 49.

${ }^{16}$ MARCONDES, Danilo: Iniciação à história da Filosofia: dos pré-socráticos a Wittgenstein, 13 ed., Zahar, Rio de Janeiro, 2010. Pág. 44.

${ }^{17}$ Apud STRASSBURGER, Hélio: Poéticas da singularidade, E-papers, Rio de Janeiro, 2007. Pág. 93. 
Wittgenstein: "este livro será talvez apenas compreendido por alguém que tenha uma vez ele próprio já pensado os pensamentos que são nele expressos - ou pelo menos pensamentos semelhantes" ${ }^{18}$. Ou, ainda, relações com as demonstrações de Santo Agostinho em seu diálogo sobre o Mestre, "De Magistro", encerradas na conclusão de que "as coisas não se aprendem pelas palavras [que repercutem exteriormente]", "mas pela verdade que ensina interiormente" ${ }^{\prime 19}$.

Conscientes das analogias apressadas, histórica e logicamente equivocadas, com os céticos, com o sofista, com o poeta-filósofo e com o filósofo analítico e das comparações parcialmente acertadas com o sentido agostiniano, é importante assumir a singularidade imanente do criadouro de conceitos de Rohden. Ele fala da perspectiva de uma possibilidade real da educação do ser humano integral. Tal integralidade poderia ser traduzida como um ego físico-emocional-intelectual instruído nos fatos integrado em um Eu espiritual educado nos valores ${ }^{20}$. Faz-se importante aqui uma diferença fundamental entre educação e instrução.

A primeira se refere a uma atividade "eminentemente individual" 21 ou "radicada no indivíduo",22, cujo vínculo social está naquilo que dela se propaga na sociedade. Uma boa analogia para essa propagação, diz Rohden, seria o fenômeno da indução no eletromagnetismo ${ }^{23}$. A educação trata da formação do sábio, aquele

18 WITTGENSTEIN, Ludwig: Tratado lógico-filosófico, tradução de M. S. Lourenço, Calouste Gulbenkian, Lisboa, 1987. Pág. 27.

${ }_{19}^{19}$ AGOSTINHO: De magistro, tradução de Ângelo Ricci, 2. ed., Abril Cultural, São Paulo, 1980.

${ }^{20}$ ROHDEN, Huberto: Educação do homem integral, Martin Claret, São Paulo, 2005a. Págs. 39-41.

${ }^{21}$ ROHDEN, Huberto: Novos rumos para a educação, Martin Claret, São Paulo, 2005b. Págs. 125, 127.

${ }^{22}$ Idem. Pág. 125.

${ }^{23}$ ROHDEN, Huberto: Educação do homem integral, Martin Claret, São Paulo, 2005a. Págs. 16, 19. 
que se torna necessariamente saudável e feliz. Já instrução é atividade eminentemente social, atrelada a ministérios e políticas públicas: da alçada da inteligência e da formação do erudito, que deverá possuir domínio de certos conhecimentos técnicos e factuais ${ }^{24}$.

Se não é difícil perceber a possibilidade de falarmos, com Rohden, em uma docência ou conduta filosófico-clínica instrutora, não parece tão imediata a ideia de uma docência ou conduta filosóficoclínica educadora. Afinal, sendo a educação "eminentemente" individual, um processo de quem se educa, podemos falar na educação de um pelo outro, no caso, do partilhante ${ }^{25}$ pelo filósofo? Considerando-se a lógica da Filosofia Universalista de Rohden, a resposta é sim. E esta afirmação só é possível quando inserida em um paradoxo, expresso no que o filósofo chama de "o problema paradoxal da educação". A prática educativa se dá por um processo semelhante à já citada indução eletromagnética, quando um corpo recebe a influência de uma força a partir do momento em que entra em contato com um campo magnético. O filósofo educador, que antes de tudo movimenta-se educativamente na realização em si dos próprios valores, é aquele que, dada essa condição, serve de guia e mentor, "não tanto pelo que diz ou faz, mas, sobretudo, pelo que é" ${ }^{26}$. Se o gesto factual do professor ensina ${ }^{27}$, também educa aquilo que ele, singular e autenticamente, valorativamente se torna ou vem a ser.

\footnotetext{
${ }^{24}$ Idem.

${ }^{25}$ Em Filosofia Clínica dá-se o nome de partilhante ao cliente, paciente, orientando, consulente ou consultante.

${ }^{26}$ ROHDEN, Huberto: Novos rumos para a educação, Martin Claret, São Paulo, 2005b. Pág. 17.

${ }^{27}$ RIOS, Terezinha Azerêdo: "O gesto do professor ensina", disponible on-line en http://www.acervodigital.unesp.br/handle/123456789/25 (último acceso $11 \mathrm{de}$ maio de 2017).
} 
Lembrando-se da etimologia latina de educar - educere, que quer dizer eduzir, conduzir para fora - o educador é, para Rohden, "um 'edutor', alguém que 'eduz' do seu educando o que nele dormita de melhor e mais puro". Algo como a "luz solar [que] desperta e desenvolve na semente a planta que nela existe potencialmente" 28 . Sendo o espaço filosófico clínico aplicado um espaço de (auto) educação, entendemos que ultrapassa o tempo-espaço de encontro pessoal. O filósofo, o amante-amigo da sabedoria, avizinha-se de elementos e pessoas em interseções de qualidade variáveis ${ }^{29}$. Com sua estrutura de pensamento (EP) e funcionamento intelectivos próprios, sua historicidade, circunstâncias e estilo singulares, oferece um serviço de acolhida e envolvimento sinceramente compromissado com seu próprio desenvolvimento, sua trajetória e seus interesses. E o partilhante pode abertamente ser comunicado disto. Um exercício do Ubuntu africano: sou pois que somos.

Ditas estas palavras, certos de futuros aprofundamentos, trabalhos e composições, partimos à exposição do texto que serviu às conversas dialógicas dos filósofos clínicos com José Barrientos Rastrojo e parte de seu pensamento ${ }^{30}$.

\footnotetext{
${ }^{28}$ ROHDEN, Huberto: Novos rumos para a educação, Martin Claret, São Paulo, 2005b. Pág.17.

${ }^{29}$ É do jogo de linguagem filosófico clínico a consideração de 5 tipos de interseção entre Estruturas de Pensamento (EPs): positiva, negativa, indeterminada, confusa e em transição.

${ }^{30}$ Em especial, dedicamos esta publicação à memória da Dra. Marta Claus, diretora geral do Instituto Mineiro de Filosofia Clínica. Ela transfigurou-se para outra forma de energia algumas semanas após o evento.
} 


\section{Filosofia Aplicada à Pessoa: dialogando com José Barrientos Rastrojo}

\section{Estabelecer um diálogo}

Em Portugal, no I Curso Luso Brasileiro de Aconselhamento Filosófico, ano passado, 2016, o Prof. Márcio José, de CampinasSP, chamou-me a atenção para um termo que vinha aparecendo em um anteprojeto de pesquisa que mostrava a ele. Eram esboços da proposição de uma pesquisa que pudesse produzir uma conversa entre Lúcio Packter e o filósofo catarinense Huberto Rohden. _Por que ao invés de "Conversa" não muda pra "Diálogo"? - sugeria o Márcio.

Bem, na época andava inspirado em textos, fragmentos e falas da chamada rebeldia francesa e numa amiga, líder de um grupo de pesquisa que eu andava próximo, a Dra. Solange Puntel Mostafa, do campus USP de Ribeirão Preto. O "diálogo" era então um termo muito "restritivo". Restritivo de limitador, num sentido existencialmente negativo.

Praquela minha EP, quando em relações marcantes com os Tópicos VI, VII e VIII e algo de busca no Tópico $\mathrm{XI}^{31}$, o termo "diálogo" funcionava próximo a uma ideia de conversação mal-dita. Maldicção, diga-se, diariamente dita em recantos acadêmicos e nãoacadêmicos, em lares, bares, repartições, colegiados, oficinas, redes sociais, templos, etc.... Diálogo estava associado a um trabalho de convencimento, negociação, consenso democrático. Um ego intelectual se afirma, outro ego intelectual se nega. Depois, novas afirmações e negações, alternando os papéis de ativos e passivos entre egos intelectuais e seus interesses.

31 Tópico VI - Termos agendados no intelecto. Tópico VII - Termos: Universal, particular e singular. Tópico VIII - Termos: Unívoco e equívoco. Tópico XI Busca. 
O Diálogo maldito ou dito de modo afastado da Verdade soava na época - e ainda soa - como algo que deixa em segundo plano aquilo que chamamos de conversa, troca de ideia ou trocas de ideias na Ideia (ou conectadas à Ideia). Em primeiro plano, no diálogo mal dito, aparecem: uma ética do discurso (na ideia ultrapassada da cisão possível entre uma vida no discurso e uma vida na Vida); uma ética do convencimento amistoso; uma etiqueta de autoritarismo disfarçado em individual "coordenação" ou "presidência" democrática; uma etiqueta da negociação entre businessmen; uma ética do consenso democrático.

\section{Consenso democrático não é diálogo}

Acreditamos, entretanto, que ainda haja bons criadouros para o conceito Democracia em nossos tempos atuais. Sobretudo, ao se projetar a possibilidade de experiências factuais com valores como, por exemplo: tolerância; respeito à diferença; "comunicação, cooperação e livre interação" em substituição ao "uso da força para solucionar os conflitos" ${ }^{\text {"32; }}$ isegoria (igual direito à manifestação de opinião e uso da palavra), isonomia (todos devem ser tratados iguais perante as leis), isocracia (todos podem participar da execução ou gestão das instituições democráticas), liberdade (que, para nós, aproxima-se daquela que só começa quando começa a do outro e que acaba quando acaba a do outro), transparência, equilíbrio de poderes, dentre possíveis outros.

É preciso ainda atentar-se para que o conceito da democracia não sirva apenas para a insistência da centralidade de ideias como

${ }^{32}$ MURARO, Darcísio Natal: "Relações entre a filosofia e a educação de John Dewey e de Paulo Freire", en Educação Real, volumen 38, número 3, Porto Alegre, 2013. Págs. 813-829. Disponible on-line en http://www.scielo.br/scielo.php?script=sci_arttext\&pid=S2175-

62362013000300007\&lng=en\&nrm=iso (último acceso 12 de noviembre de 2017). 
"voto" (como se o voto sintetizasse, por si mesmo, todos os outros valores); "representatividade" (como se fosse possível sermos de fato representados por alguém na experiência dos valores democráticos); e "vontade da maioria" (como se vontades das minorias privilegiadas não existissem ou nunca fossem travestidas de maiorias ou que vontades não devessem ser substituídas por necessidades de Beleza, Bondade e Ajustamento com o Cósmico). Temos acreditado ser salutar começar a estabelecer relações com o conceito de Cosmocracia, conforme aparecia numa série de conferências realizadas no Ministério da Educação, no Rio de Janeiro, durante o Governo de JK (1958-1959), pelo filósofo Huberto Rohden. Tais conferências saíram em livro com o nome "Novos rumos para a Educação"33.

Antes de vir para Belo Horizonte, aventurei-me a ler outro livro deste filósofo, que há tempos já vinha ouvindo falar, o romance teórico-filosófico ou religioso/esotérico (conforme catalogam as estantes dos sebos), "Cosmorama"34. Ali, Rohden descreve a Utopia de uma Visão Mundial, homens e mulheres vivendo em um mundo sem governadores, presidentes, prefeitos, polícias, advogados ou juízes. Também não haviam legisladores, pois não haviam leis escritas. Uma anarquia positiva ou cósmica. Na Ilha de Cosmorama, cada indivíduo havia atingido a consciência cósmica. Assim como há necessidade apenas de um governo interno nos animais puramente instintivos e inconscientes ("nadir do instinto"), também é assim no ser pleni-consciente ou integral ("zênite da intuição"). O que acontece é uma mudança de natureza deste governo, que vai de uma harmonia automática para uma harmonia consciente, em conexão ou sintonia com o Logos ou Razão.

${ }^{33}$ ROHDEN, Huberto: Novos rumos para a educação, Martin Claret, São Paulo, 2005 b.

${ }^{34}$ ROHDEN, Huberto: Cosmorama, 3. ed. modificada, Fundação Alvorada, São Paulo, 1979. 
A democracia cabe à ego-personalidade, aos seres do intelecto analítico, por natureza centrifuga e discordante. Não sendo a paz duradoura um atributo das ego-personalidades, contentam-se estas com uma paz relativa de armistício. A democracia é uma troca das leis internas, ainda em grande parte inoperantes nos seres do intelecto, por leis externas.

A nova forma de democracia, a Cosmocracia, não é vista como um produto de revolução externa, mas sim de evolução interna; não um produto de destruição ou violência física, mas algo que virá por compreensão metafísica. Talvez daqui a alguns anos poderemos, como dizia Rohden, abandonar o próprio conceito de democracia, que envolve este germe da dissolução dos egos, e abraçar a concepção de cosmocracia.

Infelizmente, sabemos que a democracia tem sido um dos grandes artifícios retóricos de nossa época. $\mathrm{E}$ de todos os lados: de quem dela fala mal e de quem dela fala bem; de quem ganha e de quem não ganha dinheiro com isso. Em um diálogo imaginário criado pelo historiador Heródoto, no século $\mathrm{V}$ a.C., aparece o seguinte texto sobre a democracia:

é impossível que ali não haja corrupção na esfera dos negócios públicos, a qual não provoca inimizades, mas sim sólidas alianças entre os malfeitores: os que agem contra o bem comum fazem-no conspirando entre si. É o que acontece, até que alguém assume a defesa do poder e põe fim às suas tramas, tomando-lhes o lugar na admiração popular, (...) tornando-se monarca ${ }^{35}$

Ou, leríamos daqui, um ditador ou governante extremista.

Se Heródoto acreditava que $\mathrm{o}$ fato de pôr fim às tramas corrompidas da democracia tornava a monocracia ou monarquia a melhor forma de governo, não é assim que pensamos. Antes, é preciso insistir no diálogo bem dito, no diálogo que não é consenso

${ }^{35}$ Apud BOBBIO, Norberto: A Teoria das Formas de Governo, tradução de Sérgio Bath, 3. ed., Universidade de Brasília, Brasília, 1980. Págs. 32-33. 
democrático, mas conversa cosmocrática, aberta e conectada com a filosofia, a ciência, a arte e a espiritualidade.

Diálogo com a Filosofia Aplicada a Pessoa do Prof. Barrientos (que, pode não parecer, mas já começou) e Diálogo entre Filósofos Clínicos de todo o país. Diálogos a la Paulo Freire! Diálogos que prezam a ética da boniteza nas relações de diálogo educativo e, como enxerga o Prof. Márcio José, na relação filosófica clínica! Que venham os diálogos conversadeiros e as conversas dialogizantes!

Pausa $^{36}$

Uma terapeuta junguiana e estudiosa da racionalidade de saúde chinesa disse acreditar, apoiada nas observações enquanto conversávamos, que às vezes parte deste que vos fala/escreve assumia um estilo de expressão que desejava tanta clareza, que acabava ficando confuso.

${ }^{36}$ Sobre a pausa enquanto silêncio, sugerimos alguns fragmentos póstumos de Clarice Lispector: "Qual é mesmo a palavra secreta? Não sei é porque a ouso? Não sei porque não ouso dizê-la? Sinto que existe uma palavra, talvez unicamente uma, que não pode e não deve ser pronunciada (...). Os que inventaram o Velho Testamento sabiam que existia uma fruta proibida. As palavras é que me impedem de dizer a verdade. / Simplesmente não há palavras. / O que não sei dizer é mais importante do que o que eu digo. Acho que o som da música é imprescindível para o ser humano e que o uso da palavra falada e escrita são como a música, duas coisas das mais altas que nos elevam do reino dos macacos, do reino animal, e mineral e vegetal também. Sim, mas é a sorte às vezes. / Sempre quis atingir através da palavra alguma coisa que fosse ao mesmo tempo sem moeda e que fosse e transmitisse tranqüilidade ou simplesmente a verdade mais profunda existente no ser humano e nas coisas. Cada vez mais eu escrevo com menos palavras. Meu livro melhor acontecerá quando eu de todo não escrever. Eu tenho uma falta de assunto essencial. Todo homem tem sina obscura de pensamento que pode ser o de um crepúsculo e pode ser uma aurora. I Simplesmente as palavras do homem". Apud BORELLI, Olga: Clarice Lispector: esboço para um possível retrato, Nova Fronteira, Rio de Janeiro, 1981. Págs. 84-85. 
A confusão, confusa que é, confunde-se. E ela - a confusão - se mistura, confundindo aquele que pensa ou tem consciência sobre ela. Nessa mistura ou nesse mix, confusão vira "entendimento difícil". Aquele difícil ou dificuldade de que fala o escrito de Gramsci, sobre que deveríamos "convencer a muita gente que o estudo é um trabalho muito fatigante", com uma prática particular própria, músculo-nervosa e intelectual; "um hábito adquirido com esforço, aborrecimento e mesmo sofrimento"37.

Sugerimos que a confusão possa, nesses casos, ser renomeada por esforço do pensamento e da consciência. Esforço de audição do eu. Esforço de audição do tu. Esforço de compreender, intuir, experimentar e saborear qualquer outra concatenação lógica pouco usual. É possível encontrar expressividades potentes mesmo passando por gagueiras, saltos lógicos, ilogicidades e proposições non sense.

Epicuro, o médico dos jardins, em sua Sentença Vaticana 29 escreveu algo assim: "Quanto a mim, com a franqueza do estudioso da natureza, prefiro dizer de modo obscuro aquilo que é útil (...), mesmo não sendo compreendido por ninguém, do que me conformar às opiniões convencionais para colher o elogio que sai espesso da multidão" ${ }^{38}$.

Anaxágoras - criador da primeira escola filosófica de Atenas e, segundo Diógenes Laércio, o primeiro a colocar o espírito (nous) acima da matéria (hyle) - vivia uma existência solitária, dedicandose à contemplação da natureza, desinteressado dos assuntos da Polis. Alguém lhe perguntou: "Não te preocupas com tua pátria?". Ele respondeu apontando para o céu: "Cala-te! Preocupo-me muito

${ }^{37}$ GRAMSCI apud ALMEIDA, José Luís Vieira de; ARNONI, Maria Elisa Brefere; OLIVEIRA, Edilson Moreira de: Mediação dialética na educação escolar: teoria e prática, Loyola, São Paulo, 2007. Pág.112.

38 EPICURO: Sentenças Vaticanas e Máximas Principais, tradução de João Quartim Moraes, Publifolha, São Paulo, 2015. 
com minha pátria!”39. Um deslocamento da forma habitual de concebermos a política. Terra-Pátria. Como escreveram Morin e $\mathrm{Kern}^{40}$ ou como cantou Lennon ("imagine all the people").

\section{Filosofia aplicada à pessoa}

O Professor José Barrientos ou Pepe, como se deixou chamar por nós, é um professor jovem, com uma produção gigante. Daqueles gigantes de mitologia e de desenho animado. Não tanto como aquele do João e do Pé de Feijão, o gigante que tem a galinha de ovos de ouro roubada e que persegue o menino faminto. Ele está mais para um gigante daquele filme de 2016, do Spielberg, "O Bom Gigante Amigo".

Em 2014, em uma das Jornadas de Estudos ao Exterior organizada pelo Instituto Packter estávamos, além de outros colegas, essa turma mineira toda: Profs. José Maurício de Carvalho, Márcio José, Kélsen Melo, Marta Claus, Giovani "el cabrón”... Fomos durante uma semana até a Universidade de Sevilla, onde participamos de um Seminário intitulado "A escola de Ortega e a de Lúcio Packter". Nosso anfitrião foi o professor Barrientos, que na ocasião lançou um livro conjunto com os Doutores Packter e José Maurício, a obra "Introdução à Filosofia Clínica e Filosofia Aplicada: Avaliações e Fundamentações". Além de uma entrevista ("Sobre a Filosofia Prática"), o Prof. Pepe fez constar dois sintéticos e esclarecedores capítulos: "Introdução à Filosofia Aplicada" e "A orientação Filosófica (ou Filosofia Aplicada à Pessoa) a partir das raízes zambranianas".

Em maio deste ano, vários elementos sincrônicos convergiram. Um evento que temos coordenado em cidade do interior paulista,

${ }^{39}$ LAÊRTIOS, Diógenes: Vidas e doutrinas dos filósofos ilustres, tradução de Mário da Gama Kury, 2 ed., UnB, Brasília, 2008. p.49.

${ }^{40}$ MORIN, Edgar; KERN, Anne Brigitte: Terra-pátria, tradução de Paulo Neves, 6 ed., Sulina, Porto Alegre, 2011. 
Batatais-SP, chamado "Encontro Filosófico"; uma pós-graduação latu sensu em Aconselhamento Filosófico criado em Universidade próxima; um encontro de alunos deste curso com o Prof. Pepe em São Paulo, Capital, em evento organizado pela colega filósofa clínica Dra. Monica Aiub; mensagens trocadas pelo Facebook; contatos com a coordenação do curso de Aconselhamento na Universidade mencionada e o aceite do Prof. Barrientos para ir a minha pequena cidade, donde ministra duas palestras transmitidas via Internet. Uma delas teve como título "Filosofia Aplicada à Pessoa". Pude ali estar presente e creio que muito da inspiração para a convocação/convite do IMFIC para que estivesse aqui neste evento a falar/escrever deste assunto se deu por conta destes movimentos espaço-temporais.

Uma das coisas que ocorreu foi basear-me para esta conversa na tese de doutorado do Prof. Barrientos, escrita de 2005 a 2009 e apresentada ao Departamento de Metafísica, Correntes Atuais da Filosofia, Ética e Filosofia Política da Universidade de Sevilla. Intitulada "Vetores Zambranianos para uma teoria da Filosofia Aplicada a Pessoa", a tese tem dois volumes em um total de 1384 páginas. Nesta tese, além da expressão "Filosofia Aplicada", aparecem "Filosofia Aplicada a Grupos", "Filosofia Aplicada à Intimidade" e a "Filosofia Aplicada à Pessoa". O foco, entretanto, que suspeito estar se concentrando no decorrer dos últimos anos, é a "Filosofia Aplicada à Pessoa" que, além de estar no título da tese associada à Filosofia de Maria Zambrano, aparece nos títulos de subcapítulos do Capítulo 1 e nos Capítulos 6, 7, 8 e 9 (todos os do segundo volume da tese $)^{41}$.

Dado que nem só de filosofia vive cá este filósofo, não houve tempo objetivo para ler a obra na íntegra. Mas, quanto a isto, recebi

${ }^{41}$ BARRIENTOS RASTROJO, José: Vectores zambranianos para uma teoria de la filosofia aplicada a la persona. Tesís Doctoral (Filosofía) - Departamento de Metafísica, Corrientes Actuales de la Filosofía, Ética y Filosofía Política de la Universidad de Sevilla. Sevilla, p.1384. 2009. 
o alento do próprio Barrientos via mensagens no celular, de que a tese era "antiga", já com quase 10 anos e que já haviam muitos avanços desde sua publicação. Animado que ficou com a possibilidade deste diálogo, passou-me uma série de slides atualizados utilizados mês passado, na Universidade de Sevilla.

Para pensar esta conversa dialogal mais direta da Filosofia Clínica e dos filósofos clínicos com o Prof. Barrientos, além dos slides e dos capítulos do livro lançado na Jornada de Estudos, revi a palestra em Batatais-SP e procurei ser fiel - como disse ao Pepe aos encontros que tivemos e teremos.

Solicitei a ele uma relação de suas obras publicadas ao que me mandou de imediato seu currículo em “.pdf”. Ali, além de verificar sua primeira graduação de 1998 a 2001 em Enfermagem, na Escola Universitária de Ciências da Saúde da Universidade de Sevilla, encontrei nomeadas suas 203 publicações, dentre as quais 31 livros e 110 capítulos de livros.

Em Batatais, nossa rápida conversa em torno de um café da manhã com pães de queijo (e viva Minas Gerais no interior de São Paulo!), girou no sentido de que a Filosofia Clínica e a Filosofia Aplicada precisavam começar a falar de suas proximidades e semelhanças de práticas e de sentidos. Mais do que frisar suas diferenças (como, aliás, eu próprio vinha fazendo em escritos e artigos, especialmente sobre as diferenças de método e abrangência entre $\mathrm{o}$ Aconselhamento Filosófico e a Filosofia Clínica).

Em Sevilla, de fato, o que nos ficava das aulas do grupo com o Prof. Lúcio fora da Universidade era que enquanto a Filosofia Aplicada se concentrava determinantemente no tópico $\mathrm{X}$ da $\mathrm{EP}^{42}$, Estruturação de Raciocínio, e em alguns outros possíveis como XVI (Significado), XVII (Armadilha Conceitual), XX (Epistemologia), etc., a Filosofia Clínica mostrava-se com uma

${ }^{42}$ Em Filosofia Clínica a Estrutura de Pensamento (EP) é estudada levando-se em consideração trinta tópicos em relação. 
abertura bem maior de repertório para situações singulares diversas. O método, o instrumental da historicidade, os 30 tópicos, os 32 submodos, as 5 ou 7 categorias, a matemática simbólica, as sinonímias; a escola filosófica da FC, os estudos sempre em continuidade e evolução feitos pelo mestre filósofo sistematizador e colaboradores próximos, com conteúdos sendo abertos gradativamente a seus discípulos em semanas de estudos, cursos gravados e transmitidos pela Internet e jornadas peripatéticas; a linguagem e os percursos metodológicos compartilhados em eventos como nesse Segundo Diálogo: tudo isso, sinais da riqueza infinita e inesgotável da Filosofia Clínica em sua diferenciação com outros movimentos.

No livro lançado em Sevilla, Prof. Barrientos apresenta um possível papel ontológico ou metafísico da consulta filosófica. Mais do que uma atuação para pensamentos e crenças modificados, busca-se a ação e a transformação na vida da pessoa, em seu ser (ondas se espalhando pelo pensar, pelo sentir e pelo fazer). $\mathrm{O}$ Professor vai nos falar, inspirando-se em estudos aprofundados do pensamento da filósofa Maria Zambrano, do sentido de aproximar o consultante do abismamento ou do encontro dele com seu abismo existencial. Será necessário "descer ao maior desconsolo para adquirir o saber transformador" de uma mente frutificada ${ }^{43}$.

É reparável que no capítulo seguinte, escrito pelo Prof. Packter, apareça "a menina das páginas de Goethe", que naturalmente naquela sua existência singular, precisaria caminhar muito para chegar ao abismo. Uma menina que tinha em seu mundo como representação pessoas em um abismo sobre sua cabeça. Pessoas que prometiam promover sua caminhada para o Sol, mas que lhe

${ }^{43}$ RASTROJO BARRIENTOS, José. En PACKTER, Lúcio (Org.). Introdução à filosofia clínica e filosofia aplicada: avaliações e fundamentações, FiloCzar, São Paulo, 2014a. p. 47-72. Pág.67. 
causavam dores, desconfortos, aborrecimentos, medos. E o Sol dela tinha borboletas e passarinhos: era diferente ${ }^{44}$.

Prof. Packter segue abrindo outras tantas possibilidades de localizações existenciais: os elementos circunstanciais retrógrados; a falta de fundamentos epistemológicos seguros para defender uma "chatice" ou até uma "enfermidade" existencial representada como a politicamente correta pregação do equilíbrio, harmonia e serenidade como saúde para todos; as muitas variações possíveis de autoria na escritura existencial de uma vida; as limitações das "asas de ferro e dos motores precários das perguntas e respostas" de nossa Filosofia arcaica; o futuro sinalizando para um Nós maior que o eu; variações possíveis de descrições científicas de neurônios e grupos de neurônios com singularidades de função e atuação muito próprias; e casos peculiares de corpos se comportando como almas ou se transformando em outras coisas que não sejam um corpo ${ }^{45}$.

Inevitável não pensar nas diferenças de discursos da Filosofia Clínica.

A obra do Prof. Barrientos é, como já insinuamos, de envergadura impressionante. Qualquer tentativa de reduzi-la a poucas palavras seria uma afronta à riqueza de movimentos e da fértil criatividade presente, por exemplo, na série de "exercícios práticos" propostos em sua tese de doutorado, ou nas práticas de oficinas sapienciais estoicas, consultas, práticas de docência universitária e pesquisas científicas (como a recente investigação, financiada pela Universidade de Chicago, sobre a possibilidade da melhoria da sabedoria nas pessoas via participação em oficinas filosóficas).

O que destacamos do material consultado para esta comunicação é apenas uma pequena parte que pode promover movimentos

44 PACKTER, Lúcio: "Filosofia Clínica: um prefácio" en PACKTER, Lúcio (Org.). Introdução à filosofia clínica e filosofia aplicada: avaliações e fundamentações, FiloCzar, São Paulo, 2014. Págs. 73-82.

${ }^{45}$ Idem. 
interessantes de avaliação das práticas presentes e futuras dos filósofos clínicos em interseção positiva com a Filosofia Aplicada. Barrientos distingue entre duas Filosofias Aplicadas (FA). Uma Lógico Argumentativa (FALA) e outra Experiencial (FAE). Destaca que não se trata de eleger uma em detrimento da outra, mas que, enquanto a primeira está restrita à racionalidade moderna cartesiana-hegeliana e se foca na melhoria do pensar e na depuração de conteúdos verdadeiros, a FAE se abre à materialização de transformações ontológica-antropológicas. O ser da pessoa como um todo, integralmente, em seu fazer, sentir, pensar e crer é afetado quando a FA se faz pela racionalidade experiencial. A FAE é complemento e superação integradora da FALA (e aqui, somos convidados a pensar na poética dos homônimos: FALA e fala).

O conceito-chave é a experiência. É ela a vivência intensa, crucial, na própria pele, de um acontecimento que impacta o sujeito em seu SER. A FA focada na racionalidade da experiência é, segundo Barrientos, um modelo compreensivo ou uma hermenêutica ontológica ou espiritual. Vivência se transforma em experiência quando há valentia para se forjar uma abertura ontológica em conexão com o ser. O impacto com o SER é a descoberta da vocação, do sentido de vida (como arrisco dizer, diria também Viktor Frank1), "a chamada do ser da pessoa"46.

A finalidade da FAE, diz Barrientos, "é gerar seres que se avizinhem da verdade metafísica". É aumentar "a probabilidade de fusão entre ambos, a ponto de assegurar o fortalecimento da tendência de que não seja o sujeito quem fale ou atue por si mesmo, mas que seja a verdade que o faça por meio dele" ${ }^{, 47}$.

${ }^{46}$ RASTROJO BARRIENTOS, José: En PACKTER, Lúcio (Org.). Introdução à
filosofia clínica e filosofia aplicada: avaliações e fundamentações, FiloCzar, São
Paulo, 2014a. p. 47-72. Pág. 49.
47 RASTROJO BARRIENTOS, José: Introdução à Filosofia Aplicada. In:
PACKTER, L. (Org.). Introdução à filosofia clínica e filosofia aplicada: 
Diz-se que é possibilitado ao consulente sair de si mesmo e buscar um ser mais amplo que ele mesmo e no qual acaba se integrando. A pessoa descobre o real ontológico, experimenta-o, vivencia-o. A experiência do sentir básico, instantes privilegiados em que compreendemos ou temos a impressão da realidade, revela o que é essa entidade e é o que vai possibilitar a maturação ontológica e a assunção autêntica da pessoa.

Não posso deixar de reparar aqui uma grande semelhança com uma das definições de Huberto Rohden para a Filosofia: "o processo de saber por experiência imediata e direta o sabor da suprema e última Realidade, e esse saborear se chama Verdade"48. Filosofar, como diria Maria Zambrano, um "decifrar o sentir originário" ", entender $o$ verbo dentro do ato que o verbo comunica.

Para além da racionalidade cartesiana e do saber científico-técnico, a FAE amplia rumo à poesia, à mística, ao simbolismo e à narratividade. $\mathrm{O}$ consulente encontra um caminho onde vida e mente se enlaçam numa dança satisfatória.

Nos últimos slides encaminhados pelo Prof. Pepe, a maturação ontológica do consulente sob processo da FAE é comparada aos processos de captação do secreto da experiência operada pelas pessoas que se iniciam em sendas de sabedoria, seja nas escolas de formação médica ou de artes, seja nas escolas sapienciais clássicas do Oriente, Ocidente, Américas Central e do Sul.

Autenticidade, maturação metafísica, conhecimento do caminho de si: o que pensarmos disso em nossas práticas clínicas? Nós,

avaliações e fundamentações. São Paulo: FiloCzar, 2014b. p. 15-46. Pág. 38.

${ }^{48}$ ROHDEN, Huberto: Filosofia contemporânea: o drama milenar do homem em busca da verdade integral, Martin Claret, São Paulo, 2008. Pág.16.

49 RASTROJO BARRIENTOS, José: “A orientação filosófica (ou filosofia aplicada à pessoa) a partir das raízes zambranianas" en PACKTER, Lúcio (Org.): Introdução à filosofia clínica e filosofia aplicada: avaliações e fundamentações, FiloCzar, São Paulo, 2014a. p. 47-72.Págs. 48-49. 
filósofos clínicos que serenamente buscamos respeitar os fundamentos essenciais dos jogos de linguagem da FC.

É ensinado que o objetivo central da clínica filosófica é o exercício existencial da pessoa, porém um exercício que busca ajustes subjetivos da EP que conosco partilha trajetórias. E aqui uma dimensão de Política. O que dialogar com Prof. Barrientos quando este nos fala que a ação do filósofo é crítica por natureza, e que "o foco a apreender não é subjetivo, mas uma esfera que transcende a espaço-temporalidade individual" ${ }^{\text {"50 }}$ ? Ou que a maturação ontológica nada tem a ver com caprichos egocêntricos, linhas ideológicas neocapitalistas acríticas ou moldes dogmáticos "individualistas cegos por uma tendência subjetivista" 51 ?u, ainda, que "o alvo do procedimento é a verdade, o conhecimento ou o aprofundamento existencial antes que a felicidade, a cura ou a reabilitação dentro dos cânones" de bem-estar promovidos pelo sistema econômico capitalista em uma sociedade neoliberal ${ }^{52}$ e, acrescentamos, líquida?

É verdade que há certa potência quando Nietzsche, em "A Gaia Ciência", escreveu que "enxergar semelhanças e fabricar igualdades é característica de olhos fracos" e que aquele que deseja "mediar entre dois pensadores decididos" tem como um de seus atributos a mediocridade e "não tem olhos para o que é único" ${ }^{53}$.

\footnotetext{
${ }^{50}$ Idem. Pág. 50.

51 RASTROJO BARRIENTOS, José: "Introdução à Filosofia Aplicada" en PACKTER, Lúcio (Org.): Introdução à filosofia clínica e filosofia aplicada: avaliações e fundamentações, FiloCzar, São Paulo, 2014b. Págs. 15-46. Pág. 19.

52 RASTROJO BARRIENTOS, José: "A orientação filosófica (ou filosofia aplicada à pessoa) a partir das raízes zambranianas" en PACKTER, Lúcio (Org.): Introdução à filosofia clínica e filosofia aplicada: avaliações e fundamentações, FiloCzar, São Paulo, 2014a. p. 47-72. Pág. 58.

${ }^{53}$ NIETZSCHE apud SALVIANO, José Oliveira Silva: Labirintos do nada: a crítica de Nietzsche ao niilismo de Schopenhauer, Edusp, São Paulo, 2013. Pág.11.
} 
É-nos mais atual, entretanto, até pelo diálogo que aqui se conversa, como Morin também disse, a hora de considerar que isolar e separar pode dar lugar a distinguir e unir. Como escreveu Rohden ${ }^{54}$ :

ser filósofo quer dizer descobrir as linhas-mestras através da desconcertante e, por vezes, caótica, multiplicidade de sistemas e correntes; enxergar essas linhas como torrentes convergentes do mesmo pensamento; ver o simbolizado através dos símbolos, a unidade através da multiplicidade; penetrar os invólucros opacos da letra e descobrir por detrás, ou antes, ou dentro dessas paredes opacas, feitas transparentes, a luz do espírito; ver a luz branca ou incolor como causa única de todas as cores do prisma solar.

Enquanto discípulos da escola da Filosofia Clínica, poderíamos pensar naquilo que algumas tradições colocam acerca dos vícios e valores da senda do discipulado. Prezam-se as virtudes da devoção (mediante a fé), da investigação (vontade de buscar a Verdade) e do serviço (em pensamentos e atos). E atentam-se aos vícios do fanatismo (excesso de devoção), do intelectualismo (excesso de investigação) e do mecanicismo (excesso de serviço).

Fé em grego é pistis, e "ter pistis", em grego, é expresso pelo verbo pisteuein, ter fidelidade, estar harmonizado e sintonizado, ajustado com a Verdade. Quando a alma humana e o Logos estão sintonizados ou conectados é que pode o ser humano afirmar ter fé. Em latim, fé é fides e ter fé precisou buscar um verbo com outro radical, credere, que em português resultou em "crer", algo incerto, vago, nebuloso. Crer não é ter certeza, mas é acreditar que aquilo pode ser certo, com certa probabilidade de não ser. Mas, a investigação filológica do termo Fé não tem a ver com isso. Fé é verbo pronunciado a partir da experiência da sintonia ${ }^{55}$.

\footnotetext{
${ }^{54}$ ROHDEN, Huberto: Filosofia contemporânea: o drama milenar do homem em busca da verdade integral, Martin Claret, São Paulo, 2008. Pág.20.

55 ROHDEN, Huberto: Paulo de Tarso: o maior bandeirante do evangelho,
} 
Enquanto conduta, a FC pode ser rotulada de relativista e subjetivista, porém, como esclareceu Lúcio Packter em uma de suas falas, ela é assim apenas em partes. Para outra de suas partes, a maioria, ela é objetivista. Temos Fé que é na objetividade filosófica de verdade universal onde se encontram os esforços mundiais da Ética, da Filosofia Aplicada e da Filosofia Clínica.

Como dizia o mineiro Drummond, de mãos dadas ${ }^{56}$.

\section{Bibliografia}

AGOSTINHO: De magistro, tradução de Ângelo Ricci, 2. ed., Abril Cultural, São Paulo, 1980.

ANDRADE, Carlos Drummond de: Sentimento do mundo, 1940, Companhia das Letras, São Paulo, 2012.

ALMEIDA, José Luís Vieira de - ARNONI, Maria Elisa BrefereOLIVEIRA, Edilson Moreira de: Mediação dialética na educação escolar: teoria e prática, Loyola, São Paulo, 2007. Pág.112.

BOBBIO, Norberto: A Teoria das Formas de Governo, tradução de Sérgio Bath, 3. ed., Universidade de Brasília, Brasília, 1980.

BORELLI, Olga: Clarice Lispector: esboço para um possível retrato, Nova Fronteira, Rio de Janeiro, 1981.

18ed., Martin Claret, São Paulo, 1996. Págs. 304-305.

56 "Não serei o poeta de um mundo caduco / Também não cantarei o mundo futuro / Estou preso à vida e olho meus companheiros / Estão taciturnos mas nutrem grandes esperanças / Entre eles, considero a enorme realidade / O presente é tão grande, não nos afastemos / Não nos afastemos muito, vamos de mãos dadas / Não serei o cantor de uma mulher, de uma história / Não direi os suspiros ao anoitecer, a paisagem vista da janela / Não distribuirei entorpecentes ou cartas de suicida / Não fugirei para as ilhas nem serei raptado por serafins / O tempo é a minha matéria, o tempo presente, os homens presentes / A vida presente". En: ANDRADE, Carlos Drummond de: Sentimento do mundo, 1940, Companhia das Letras, São Paulo, 2012. 
BRASIL: Clínica ampliada e compartilhada, Ministério da Saúde, Secretaria de Atenção à Saúde, Política Nacional de Humanização da Atenção e Gestão do SUS, Ministério da Saúde, Brasília, 2010. EPICURO: Sentenças Vaticanas e Máximas Principais, tradução de João Quartim Moraes, Publifolha, São Paulo, 2015.

FATTURI, Arturo: Teoria do conhecimento I: livro didático, UnisulVirtual, Palhoça, 2009. Livro didático da disciplina de Teoria do Conhecimento I do curso $\mathrm{EaD}$ de bacharelado em Filosofia da Unisul - Universidade do Sul de Santa Catarina FRANKL, Viktor: A vontade de sentido: fundamentos e aplicações da Logoterapia, tradução de Ivo Studart Pereira, Paulus, São Paulo, 2011.

LAÊRTIOS, Diógenes: Vidas e doutrinas dos filósofos ilustres, tradução de Mário da Gama Kury, 2 ed., UnB, Brasília, 2008.

LARROSA BONDÍA, Jorge: Tremores: escritos sobre experiência, Autêntica, Belo Horizonte, 2015.

MARCONDES, Danilo: Iniciação à história da Filosofia: dos présocráticos a Wittgenstein, 13 ed., Zahar, Rio de Janeiro, 2010.

MORIN, Edgar; KERN, Anne Brigitte: Terra-pátria, tradução de Paulo Neves, 6 ed., Sulina, Porto Alegre, 2011.

MURARO, Darcísio Natal: "Relações entre a filosofia e a educação de John Dewey e de Paulo Freire", en Educação Real, volumen 38, número 3, Porto Alegre, 2013. Págs. 813-829. Disponible on-line en http://www.scielo.br/scielo.php?script=sci_arttext\&pid=S217562362013000300007\&lng=en\&nrm=iso (último acceso 12 de noviembre de 2017).

PACKTER, Lúcio: "Filosofia Clínica: um prefácio" en PACKTER, Lúcio (Org.): Introdução à filosofia clínica e filosofia aplicada: avaliações e fundamentações, FiloCzar, São Paulo, 2014. Págs. 7382.

RASTROJO BARRIENTOS, José: Vectores zambranianos para uma teoria de la filosofia aplicada a la persona. Tesís Doctoral (Filosofía) - Departamento de Metafísica, Corrientes Actuales de la 
Filosofía, Ética y Filosofía Política de la Universidad de Sevilla. Sevilla, p.1384. 2009.

RASTROJO BARRIENTOS, José: "Introdução à Filosofia Aplicada" en PACKTER, Lúcio (Org.): Introdução à filosofia clínica e filosofia aplicada: avaliações e fundamentações, FiloCzar, São Paulo, 2014b. p. 15-46

RASTROJO BARRIENTOS, José: "A orientação filosófica (ou filosofia aplicada à pessoa) a partir das raízes zambranianas" en PACKTER, Lúcio (Org.): Introdução à filosofia clínica e filosofia aplicada: avaliações e fundamentações, FiloCzar, São Paulo, 2014a. p. 47-72.

RICCO MEDEIROS, Leonardo: "Filosofia Clínica, Aconselhamento Filosófico, Saúde e Educação", en Educação Revista científica do Centro Universitário Claretiano, volumen 7, Batatais, 2017a. Págs. 77-108.

RICCO MEDEIROS, Leonardo: "Clinical Philosophy, Esoterism, Method and Methodology - Actions, hypotheses and experimentations at the 1st Luso-Brazilian Course of Clinical Philosophy", traducido al inglés por Marcelo Batistella, en Partilhas: Revista de Filosofia Clínica do IMFIC, volumen 3, Poços de Caldas, 2016. Págs. 105-119.

RICCO MEDEIROS, Leonardo: "El filósofo (clínico) y el tartamudo extranjero", traducido al español por Marcelo Batistella, en Partilhas: Revista de Filosofia Clínica do IMFIC, volumen 4, Poços de Caldas, 2017b. Págs. 145-158.

RIOS, Terezinha Azerêdo: "O gesto do professor ensina", disponible on-line

en http://www.acervodigital.unesp.br/handle/123456789/25 (último acceso 11 de maio de 2017).

ROHDEN, Huberto: Cosmorama, 3. ed. modificada, Fundação Alvorada, São Paulo, 1979.

ROHDEN, Huberto: Educação do homem integral, Martin Claret, São Paulo, 2005a. 
ROHDEN, Huberto: Filosofia contemporânea: o drama milenar do homem em busca da verdade integral, Martin Claret, São Paulo, 2008.

ROHDEN, Huberto: Novos rumos para a educação, Martin Claret, São Paulo, 2005b.

ROHDEN, Huberto: $O$ espírito da filosofia oriental: o drama milenar do homem em busca da verdade integral. 3. ed. Martin Claret, São Paulo, 2013.

ROHDEN, Huberto: Paulo de Tarso: o maior bandeirante do evangelho, 18ed., Martin Claret, São Paulo, 1996.

SALVIANO, José Oliveira Silva: Labirintos do nada: a crítica de Nietzsche ao niilismo de Schopenhauer, Edusp, São Paulo, 2013.

SERRANO, Alan Indio: $O$ que é psiquiatria alternativa, Brasiliense, São Paulo, 1986.

STRASSBURGER, Hélio: Poéticas da singularidade, E-papers, Rio de Janeiro, 2007.

WITTGENSTEIN, Ludwig: Tratado lógico-filosófico, tradução de M. S. Lourenço, Calouste Gulbenkian, Lisboa, 1987.

YASUI, Sílvio: Rupturas e encontros: desafios da Reforma Psiquiátrica Brasileira, Tese (Doutorado em Ciências na área de Saúde) - Escola Nacional de Saúde Pública da Fundação Oswaldo Cruz, Rio de Janeiro, 2006. 